\title{
Environmental Local Wisdom Represented in Communication Patterns of Batimbang Tando in Minangkabau's Culture
}

\author{
Adnania Nugra Heni ${ }^{1 *}$, Agus Subiyanto ${ }^{2}$ \\ ${ }^{1}$ Department of Linguistics, Faculty of Humanities, Diponegoro University, Semarang - Indonesia \\ ${ }^{2}$ Department of Linguistics, Faculty of Humanities, Diponegoro University, Semarang - Indonesia
}

\begin{abstract}
The forms of culture are diverse. One of them is a wedding ceremony. In Minangkabau's culture, several processes have to be done before the wedding ceremony, and one of them is Batimbang Tando (engagement). This research aims to discuss the communication patterns in the process of Batimbang Tando in Minangkabau's culture. This research is descriptive qualitative using ethnography of communication approach. The data in this research were obtained from the informants involved in the events. To collect the data, the researchers used nonparticipant observation by interviewing with note-taking technique. To analyze the data, the researchers used Hymes's theory of SPEAKING. The result shows that the Batimbang Tando event took place in the boy's house. In this event, there are several communicative events, such as; Pasambahan, batuka tando, makan bajamba and manantuan ari. In this event, the communication process (pasambahan) uses subtle Minangkabau languages in the form of pantun and talibun. The use of plants like Siriah (betel leaf) and Pinang (areca nut) to symbolize life in Pasambahan indicated that culture and environment could not be separated as they function to preserve harmonious relations between nature and cultural life.
\end{abstract}

\section{Introduction}

Indonesia is known for its cultural diversity. This cultural diversity comes from various ethnic groups spread across Indonesia. This culture itself is a characteristic and knowledge possessed by a particular group in which there are elements of language, religion, social habits, music, and art. According to Oswalt in Duranti (1997: 24) [1], culture is a learned behaviour and the same characteristic pattern in a community group. This means that culture has been learned from a family or a member of a community from generation to generation. The forms of this culture are also very diverse, depending on the social conditions of the people.

One form of this culture can be found in the wedding ceremony. In Minangkabau's culture, several processes have to be done from before until the wedding day, such

* Corresponding author: adananianugraheni@gmail.com 
as Maresek, Batimbang tando, Bainai Night, Akad nikah/ marriage contract, Manjapuik Marapulai, wedding party / baralek. Each of the above processes has its unique characteristics because some are not found in other cultures. This unique cultural example is suitable for further investigation, primarily since Indonesia is known for its diverse cultures. This case can be further studied by using the ethnography of communication approach. According to Koentjaraningrat in Kuswono (2008) [2], ethnography of communication is the development of linguistic anthropology, which is understood in terms of communication. Ethnography itself is a detailed description of the behaviour patterns of an ethnic group.

In the process of wedding ceremonies in Minangkabau's culture, especially in Batimbang Tando / engagement, some cultural and environmental values can be seen from the process. The use of plants like betel leaf (Siriah) and areca nut (pinang) in almost formal events in Minangkabau indicates that culture and environment cannot be separated as they function to preserve harmonious relations between nature and cultural life, as also stated in Minangkabau's philosophy "Alam takambang jadi guru" which means nature is the teacher/learning by nature.

Several researchers have conducted the study about engagement or wedding ceremonies. Marta (2017) [3] conducted a study about illocutionary acts in negotiation in engagement ceremonies. In his study, he used Pasambahan texts used in engagement ceremonies in Minangkabau's culture. In her study, she found that there are three types of illocutionary acts used by the people in the ceremony, which are assertive (stating a fact or truth of something), directive (request, justifying, and asking permission), and expressive (thanked).

Novianti (2017) [4] researched language style of Pasambahan in a wedding ceremony found in Sungai Liku village in Pesisir Selatan Regency. In her study, she focused on Pasambahan script used in Manjapuik Marapulai event. She conducted the study to describe in detail and the language style used in Pasambahan Manjapuik Marapulai script. She found three language styles used in the script: comparative language style (this includes simile, metaphor, and personification), contradictory language style (hyperbole and zeugma), and alliteration.

Another study was conducted by Denafri (2018) [5], discussing politeness used in Pasambahan texts. His study aimed to reveal the politeness strategies used by Minangkabau's people in doing Pasambahan. In the result, he found the politeness strategy used in Pasambahan is politeness by using tact maxim. He also concluded that tact maxim is mainly used in Pasambahan because, in the process of Pasambahan, both speakers used allegories so that in order to understand the meaning of the speech, Minangkabau people are required to be wise and prudent.

Another study about engagement ceremonies was conducted by Haryono (2018) [6], who studied about communication strategies of Bhakalan in Maduranese ethnic in Tapal Kuda region. His study aimed to describe the communication strategies used by Maduranese ethnic in Bhakalan process. The result showed that Pangada (representative) BM È-E and BM È-B variants implement politeness strategies and BM $\hat{E}-I$ as a strategy to support the cooperative principle between the interlocutors. The indirect rhetoric style using the metaphor of plants, animals, and wind is also used in the event.

Putra Putra and Shanaz (2018) [7] researched ethnography of communication of Betawi's wedding ceremony. As a result, they found that communication behaviour in Betawi's wedding ceremony is Arakan using Ketimpring tambourine and reading shalawat before entering the bride's residence, reading Saritilawah that must be carried out at every Betawi wedding the attraction of Bukaan Palang Pintu before entering the groom's residence. Meanwhile, the verbal and non-verbal communication means in Betawi's wedding ceremony are Betawi language, the uniform used, tone of voice and eye contact. 
Another study about the ethnography of communication is also conducted by Nifmaskossu (2019) [8], who studied about directive speech act in Watmuri's wedding ceremony. In the study, he found that in Watmuri's wedding ceremony, there are 4 types of directive speech act, namely kabotkit (the act of recited speech in family gathering), bebetu (the act in wedding's process), kalabasa (the act when taking the girl from her house), and kesit (the act when paying the treasure). From the four acts above, directive speech acts mainly used are command and begging.

The present study is similar to those previous studies above in observing the event in engagement or wedding ceremony. However, the problem discussed in this study is different from those previous studies above. The present study discusses the local environmental wisdom found in the patterns of communication in Batimbang Tando / engagement event in Minangkabau's culture, which has not been studied yet by the previous researchers.

\section{Research Method}

The type of this research is descriptive qualitative. According to Sukmadinata (2006:72) [9], descriptive research is research that is aimed to describe the existing phenomena; they can be natural phenomena or man-made phenomena. This research is a qualitative study using the ethnology of communication approach. The data in this research is obtained from the informants involved in the events. To collect the data, the researcher uses participation observation by doing interviews and note-taking. To analyse the data, the researcher uses Dell Hymes's theory [10] about SPEAKING, which can be explored below:

S: Situation setting: Concrete physical circumstance of a communicative event, including time and place

P: Participants, these include: Speaker (person who conveys message), addressee (person to whom the message is sent), addresser (person who originates message or source), audience (person who present when the message is communicated, but are not directly addressed).

E: Ends / outcome: The purpose of the event from cultural or societal point of view

A: Act Sequence include content (topic or subject), and form (description of the sequence or the communicative acts, from the rigid in ritual event such as leave taking condoling and less so in conversation)

$\mathrm{K}$ : Key which include tone, manner, certain kinds of behaviour, gesture, posture, and department

I: Instrumentalities, include channel (the way a message travel) and code (languages, dialects, varieties, and registers)

$\mathrm{N}$ : Norm, include interaction (properties, speech rules), and interpretation (belief system that underlines what is in the actual word use)

G: Genre (recognizing communicative event with a share public purpose and with aims mutually understood by participant within that event).

\section{Discussion}

In analysing the communication patterns of Batimbang Tando, three points should be understood: communicative situations, communicative events, and communicative acts. These three points will be explained in detail by using Dell Hymes's theory about SPEAKING, as seen below.

The first one is the situation setting (S). In Batimbang Tando, the event takes place in the future groom's house. The event itself can be held anytime according to the agreement of both future groom and bride's families. The participants $(\mathrm{P})$ in this event are the girl and 
boy's families, which includes Mamak (uncle), juru sambah (it can be the elders or someone who is experts in doing pasambahan), parents, brothers and sisters, and other close relatives. All of the participants are primarily adults. In this event, both boys and girls who are getting engaged are prohibited from joining this event.

In this process, the most important event is laid on the sequence of the acts (A). This is because these events have the most communicative acts. In Batimbang Tando, there are some communicative events. The first one is sambah-manyambah or pasambahan. In Batimbang Tando process, pasambahan is the most important event because the goal of this process depends on the success or not the discussion is done in manyambah process. Juru sambah / experts do Pasambahan in discussing pasambahan of both families in the form of discussion.

The topic discussed is the purpose/reason of the girl's family to come to the boy's house. As stated before, the communicative act itself is in discussion to achieve agreement between both families. The language used is subtle Minangkabau language, usually in the form of pantun, and talibun which contain idiom, allusion, and a proverb, which is different from everyday language. Just no one can do this discussion. The one who will lead the discussion is a person who understands how to use the subtle language of Minangkabau and is great at choosing words. Usually, this will be done by elders or juru sambah. The discussion in pasambahan occurs between juru sambah of the girl's family, or Sutan Mudo and juru sambah from the boy's family or Sutan Diateh. The first one who opens the discussion is Sutan Mudo by saying;

Sutan Mudo (Juru sambah from the girl's family) :

(Juru sambah lift both of his hands above his head like someone's begging)

Ma angku Sutan Diateh?

Sairiang balam jo barabah

Barabah juo inggok dahulu

Sairing salam jo sambah

Sambah juo tibo bakeh angku
Where is angku Sutan diateh ?

Along with balam and barabah Barabah who perch first Along with salam and sambah Sambah comes for angku

The speech above functions as the opening act of Pasambahan. The meaning of the conversation is to show politeness and to respect each other. In this context, the speech above was uttered by Sutan Mudo as a sign of respect to Sutan Diateh. Along these lines, the communication pattern is started by giving respect to others. After that, juru sambah from the boy's family reply;

\section{Sutan Diateh (Juru sambah from the boy's family):}

Manitahlah angku Sutan Mudo

Speak it angku Sutan Mudo

The utterance above is uttered by Sutan Diateh to Sutan Mudo which implies that he gives permission to Sutan Mudo to continue carry the discussion. After hearing that, Sutan Mudo reply ;

\section{Sutan Mudo:}

Sungguahpun Sutan surang nan dituhuak, nan sarapeknyolah niniak mamakamai jo bapaksarato karajo nan bapokoksilang nan bapangkanan barado diateh rumah nangko tampek ambo manibokan sambah

Even though discussion is on Sutan It's also good for niniak mamak mother and father -

Also works that have capital Cross that have one base You all who present in this house where I present my sambah 
Panitahan nan ditibokan bakeh Sutan, iolah tantangan pihak kami nan datang. Datang bukan sumbarang datang, datang mahanta siriah jo pinang mamuhun kami ka niniak mamaksarato saganok sipangka :

Kok siriah kami yo mintak dikunyah, pinang kami mintak digatoksakitu sambah bakeh Sutan
The speaking which is set in earlier Is a challenge for us who come the visit is not any visit We deliver siriah and pinang We beg to niniak mamak Also all of sipangka (hosts) To please chew the siriah To eat the pinang That's all sambah for Sutan

TheThe first stanza contains Sutan Mudo to all of the boy's family, including niniak mamak and the boy's parents. The second stanza means that the girl's family comes to the boy's house not only to visit, but it is a special visit where they bring siriah and pinang, which is a symbol of respect in Minangkabau. It means that they come with an important thing to discuss, and they hope that the boy's family receive their intention by eating the siriah and pinang. In this step, the communication pattern is continued by asking something to others. In addition, in this step, the communicative acts are the verbal act and the non-verbal act.

The non-verbal act in this step is Sutan Mudo handed the carano, which contains Siriah, to Sutan Diateh, and then Sutan Diateh passed the carano to other members of the boy's family. After that, the boy's family ate, chopped, or just held the Siriah. This tradition of eating Siriah in Minangkabau's culture means respect to other groups. Siriah / betel leaf itself in Minangkabau symbolized respect and hospitality. In addition, Siriah and Pinang are also used to symbolize life. The bittersweet taste of Siriah and Pinang symbolized the good and bad aspects that are present in our lives. This event symbolizes the bittersweet journey that both families should experience since they will further the relationship to the next level, and whatever problems happen, they will face it together.

From the explanation above, it can be seen that cultural life and nature can not be separated. In Minangkabau, it is common to use a symbol from nature. As can be seen in the text above, the bittersweet taste of Siriah and Pinang are used to symbolize the good and bad situations in life. Furthermore, the use of other symbols from nature, for example, balam, barabah (kinds of birds) and others, indicates the closeness between society and their surrounding nature or environment, resulting in linguistic forms/utterances based on the natural surrounding. This closeness is also appropriate with Minangkabau's philosophy Alam takambang jadi guru, which means whatever is present in nature can be used as guidance in life.

After the boy's family taste the Siriah, Sutan Diateh will reply to the utterance said by Sutan Mudo before by saying;

\section{SutanDiateh:}

Siriah Sutan nan katangah alah samo kami kunyah. Pinang sagatok alah kami makan manih lah tingga diujuang lidah pahik lah luluih karakuangan namun samantangpun baitu manuruik pasa na biaso kok tembak tantu baalamaik kok cancang tantu balandasan siriah katangah bakaadaan kato katangah baurusan
Siriah which you brought has been chewed the areca nut has been eaten The sweetness left in the tip of the tongue the bitterness has passed the throat however According to the usual rule if you shoot there should be a target if you chopped there should be base siriah is brought under circumstances the words should have affairs 
tantangan siriah Sutan nan katangah yo nak mintak basiangkan nan bak hari batarangkan nan bak bulan! the challenge of Siriah which Sutan brought ask for preparation like daylight

to be brighten like the moon!

The The stanza above tells that Sutan Diateh informs Sutan Mudo that they have eaten the siriah and then, by using allusion, implicitly ask Sutan Mudo the reason for their visit. The allusion can be seen in the eighth till fourteenth lines. Besides using allusion, Sutan Diateh also asks the intention of Sutan Mudo by using indirect speech. In this step, the communicative act is in the form of asking for something.

Then, after that, Sutan Mudo, as juru sambah from the girl's family reply and tell the reason why they come by, saying;

\section{Sutan Mudo :}

Ma angku Sutan Diateh sapanjang jauah nak dijambokan sapanjang dakek nak dikakokkan maagak dihari nan dahulu kok bisiak kanlah samo kadangaran kok imbau kanlah samo kalampuan niaik di ati nan dihadang iyo nak maminang anak kamanakan Sutan nan banamo (nama pemuda yang dituju) Anak dari Angku . (nama ayahnya) Nak batali pamenan adaik jo anak kamanakan kami .(nama wanitanya) Anak dari (nama ayahnya). Ikolah niaik mukasuik kami yo nak mintak ditarimo jo hati nan suci muko nan janiah pintak nak mintak dibuliahkan kandak nak mintak bapalakukan sakitu sambah bakeh Sutan!

\author{
Where is angku Sutan Diateh \\ as long as distant has been close \\ nearby has been attached \\ considering the past \\ As whisper has been heard \\ As invitation has been fulfilled \\ our intention is \\ to propose to your nephew \\ whose name is (the boy's name) \\ the son of (the boy's father name) \\ in order to culturally link yours \\ with our niece (the girl's name) \\ The daughter of (girl's father name) \\ this is our intention \\ we hope that it will be accepted \\ with pure heart \\ request which hope to be fulfilled \\ an act which hope to be acted \\ that's all our sambah Sutan!
}

The stanza explains that they come to the boy's house to propose to him to be their niece's husband and hope that they will accept it. In this step, the communicative acts are in the form of explaining and hoping for something.

After that, Sutan Diateh replied by saying;

\section{Sutan Diateh :}

Sapanjang panitahan Sutan nan katangah alah diadaik nan bapakai alah dicupak nan baisi tapi sungguah pun nan baitu tibo dikarajo nan bak nangko rundiang ndak putuih diambo surang dielo kato jo mupakaik.

Dicari bulek nan sagolong jo niniak sarato mamak sarato urang nan patuik-patuik mananti malah Sutan sakutiko!

\author{
As Sutan speak earlier \\ already using the custom \\ already fulfilled \\ however \\ like work's decision \\ the decision is not only by me \\ It has to be discussed \\ searching for discussion \\ with niniak and mamak \\ and other involved \\ Please wait for it Sutan !
}


These utterances mean that juru sambah / Sutan Diateh can not decide the decision alone. It has to be discussed with other family members so that he asks Sutan Mudo for a time to discuss it and ask him to wait. After Sutan Mudo said they would wait, juru sambah and the boy's family began to discuss whether to accept or reject the proposal. In this step, the communicative ask is in the form of asking for something. After some time, Sutan Diateh replied;

\section{SutanDiateh:}

Maa angku Sutan Mudo?

Maaf dimintak sapuluah jari

dek rasah angku tagak mananti.

Maklumlah bakato indak sadang sapatah

bajalan indak sadang salangkah

tantangan niaik Sutan nan katangah

alah ambo paiokan jo niniak sarato mamak

mamintak Sutan di nan kadapek

kandak buliah pintak balaku

kami tarimo jo hati nan suci

alah ko sanang hati Sutan?
Where angku Sutan Mudo?
Sorry asked by ten fingers
Because you waited anxiously.
by speak is not only by one word
by walk is not only one step
Sutan's intention that was delivered
Has been discussed
As request which want to be fulfilled request permitted ask applied
we accept it with pure heart
have you been relieved Sutan?

The utterances above mean that the boy's family accept the proposal of the girl's family. In this step, the communicative acts is in the form of accepting something. As a closing act, juru sambah from the girl's family reply ;

\section{SutanMudo:}

sabana sajuak Sutan

karano pintak buliah

kandaklah balaku

sananglah raso dalam hati

Namun samantang pun baitu

adaik urang batimbang janji

lah batampuak mangko dijenjeng

lah batali mangko diirik.

Kok saik iyo nak bapamegang

kok kato iyo nak bapamacik

mako tarimolah tando dari kami.

\author{
How refreshing Sutan \\ cause the request is accepted \\ the desire is fulfilled \\ feel happy from the heart \\ However, \\ other custom weighing promise \\ cause it full it can be brought \\ Cause it is tied it can be pull \\ to cut you need a handgrip \\ you need to keep your words \\ Then please accept our sign (tando)
}

These These utterances mean that the girl's family feels relieved because their proposal is accepted, and as a sign of acceptance, they give their sign (tando). The sign (tando) itself can be Songket and ring. After receiving the sign from the girl's family, the boy's family also hands over the sign (tando) to the girl's family. After exchanging signs (tando), the next event is makan bajamba or eating together. Before eating, both juru sambah do pasambahan as a sign of politeness and respect to the host. The sambah used in this event is different from sambah used in batimbang tando. If sambah used in batimbang tando is about discussing the marriage proposal, the sambah used in makan bajamba is about politeness in offering and accepting foods. After eating together, the event is continued with discussing the marriage day or setting the day of the marriage (manantuan ari). After the date is set, the whole events are over.

The key $(\mathrm{K})$ used in this event can be divided into two; verbal and non-verbal. In verbal act, the tone used by the speakers is clear. To avoid misunderstanding, sometimes juru sambah uses emphasis on certain words when asking. The low tone intonation is used when 
conveying the objectives of their arrival and greeting all of the participants present to show respect to the hosts. In non-verbal acts, there are several gestures made by the participants. To show respect to the hosts, before starting pasambahan, juru sambah from the girl's family lift both his hands above his head like someone's begging. In addition, during speaking, he will move slightly lower his head to respect the interlocutor. The other non-verbal act can also be seen in handing carano, which contain Siriah and others. The girl's family handing carano to the host because it is mandatory in every cultural event in Minangkabau. They will be considered impolite not to bring the Siriah. As for the host is tasting or picking the Siriah from the carano handed by the other family shows respect toward the other.

The form of speech (I) used in this event (pasambahan) is subtle language in the form of pantun, and talibun which contain idiom, allusion, and proverb. The language used is more poetic and different from the language used in everyday life. Whereas the language used is a kind of spoken literature in Minangkabau's culture. Pasambahan in this event is a symbol of respect and honour each other. In the process of pasambahan, both juru sambah are discussing, so they speak in turns one after another. The turn-taking should be clear in order to avoid overlapping in speaking. In this sambah-manyambah process, there are some messages or values $(\mathrm{N})$ that can be taken; some of them are:

1. The value of respect and honour other people.

2. The value of decide something important by discussion.

3. The value of following the custom that has been done generation to generation.

4. The value of understanding the relationship between human and nature.

The end / outcome (E) of this event is to achieve agreement between both families to continue the relationship to the higher level or marriage. Besides that, this event is also held to maintain the tradition of Minangkabaunese that has been passed down from generation to generation.

The genre $(G)$ of this pasambahan event is discussion in the form of pantun, and talibun. Whereas the language used in the process is in the form of idiom, allusion, and proverb. From the explanation above, it can be seen that communicative act in this event is discussion which contain respecting, asking for something, accepting something, and agreeing to something.

\section{Conclusion}

From the finding, it can be concluded that the process of Batimbang Tando is held in the future groom's house. This event can be held anytime according to the agreement between the two families. In this event, there are several communicative events; they are; pasambahan, batuka tando, makan bajamba, and manantuan ari. The main event in this process is on pasambahan process because the success or not the agreement depends on the discussion done in manyambah process. Sambah manyambah process occurs between juru sambah from the girl's family and juru sambah from the boy's family. The communicative act in pasambahan involves respecting others, asking for something, accepting something, and agreeing. The language used in this pasambahan is subtle Minangkabau language in the form of pantun and talibun. Batimbang Tando aims to achieve agreement between both families to continue the relationship to the higher level and maintain the local tradition passed down from generation to generation. In addition, in one of the communicative acts, the guests ask the hosts to chew Siriah and eat Pinang. In this event, Siriah and Pinang are used to symbolize the bittersweet life. In addition, Siriah is also used to symbolize respect and hospitality. Environmental symbols in this event show that nature and cultural life cannot be separated as they function to preserve harmonious relations between nature and cultural life. 


\section{References}

1. D. Alessandro. Linguistic Anthropology. 24. (1997)

2. E. Kuswarno. Metode Penelitian Komunikasi Etnografi Komunikasi. (2008)

3. M.A. Redo. Bahastra. 37. 58. (2017)

4. N. Hasmi. JKPS. 2. 27. (2017)

5. D. Bram. KATA. 2. 336. (2018)

6. H. Ahmad. Lit. 17. 259. (2018)

7. P. Asaas, S. Shabrina. JLSK. 4. 104. (2018)

8. N. Regina. JPBSI. 8. 37. (2019)

9. S. N. Syaodih. Metode Penelitian Pendidikan. 72. (2006)

10. H, Dell. Foundations in sociolinguistics: An Ethnographic Approach. (1974) 